\title{
Vanadium catalysts for ethylene-norbornene copolymerization
}

\author{
Anna Bihun-Kisiel ${ }^{1)}$ *), Wioletta Ochędzan-Siodłak ${ }^{1)}$ \\ DOI: dx.doi.org/10.14314/polimery.2020.11.2
}

\begin{abstract}
Cyclic olefin copolymers (COCs) are a promising group of materials with specific, projectable properties. In this group, copolymers of ethylene and norbornene are of particular interest. A variety of transition metal complexes are used for their synthesis, mostly elements from group 4 . This review presents the application of vanadium catalysts with various types of ligands in the synthesis of ethylene--norbornene copolymers. The influence of ligands and reaction conditions on the activity of catalyst and selected properties of copolymers are described in this paper.
\end{abstract}

Keywords: vanadium catalyst, copolymerization, ethylene, norbornene, cyclic olefin copolymers.

\section{Katalizatory wanadowe $\mathrm{w}$ kopolimeryzacji etylenu z norbornenem}

Streszczenie: Kopolimery cyklicznych olefin (COCs) stanowią obiecującą grupę materiałów o specyficznych, możliwych do zaprojektowania właściwościach. Szczególnym zainteresowaniem w tej grupie związków cieszą się kopolimery etylenu z norbornenem. Do ich syntezy stosuje się różnorodne kompleksy metali przejściowych, przede wszystkim pierwiastków z grupy 4 . Artykuł stanowi przegląd literatury dotyczącej wykorzystania katalizatorów wanadowych z różnego rodzaju ligandami w syntezie kopolimerów etylenu z norbornenem. Opisano wpływ ligandów i warunków prowadzenia reakcji na aktywność oraz wybrane właściwości otrzymanych kopolimerów.

Słowa kluczowe: katalizator wanadowy, kopolimeryzacja, etylen, norbornen, kopolimery cyklicznych olefin.

Vanadium element is the second most common transition metal in the oceans with estimated concentration $50 \mathrm{nmol} / \mathrm{dm}^{3}$. In the Earth's crust it is present in quantity of $0.014 \%$ [1, 2]. Vanadium occurs in eight oxidation states in the range from -3 to +5 , with the exception of -2 , and the most stable are oxidation levels +4 and +5 [3]. The interest in vanadium complexes dates back to the early 1980 due to their ability to change the coordination number and geometry, which allows their use, among others in coordination chemistry $[4,5]$ and catalysis $[6,7]$ including polymerization of olefins [8-11].

In the last example, technologies based on Ziegler-Natta vanadium catalysts are very often used for the production of syndiotactic polypropylene [12, 13], ethylene-propylene copolymers [14], ethylene-propylene-diene terpolymers (EPM and EPDM rubbers) $[3,15]$ and cyclic olefin copolymers (COCs) [16]. In most cases, the activity and thermal stability of vanadium catalysts are lower than that of zirconium and titanium analogues. However, vanadium catalysts allow obtaining polymer

\footnotetext{
1) Opole University, Faculty of Chemistry, Chair of Chemical Technology and Polymer Chemistry, Oleska 48, 45-052 Opole, Poland.

*) Author for correspondence: abihun@uni.opole.pl
}

materials with unique properties (e.g. amorphous, homogeneous copolymers), which makes them irreplaceable in the production of synthetic rubbers $[8,10,17,18]$. The most commonly used precatalysts for the production of EPM and EPDM rubbers are $\mathrm{VCl}_{4}, \mathrm{VOCl}_{3}$, and $\mathrm{V}(\mathrm{acac})_{3}$. The last 15 years of research focused mainly on the synthesis and use of vanadium postmetallocene complexes with $\mathrm{N}$-donor, O-donor and $\mathrm{N}$, O-donor ligands for homo- and copolymerization of ethylene with $\alpha$-olefins (mainly propylene) $[8,18-26]$. For a very long time it was unknown what degree of oxidation does vanadium atom have in active center of catalysts for olefin (co)polymerization. Early studies have shown that vanadium(0) and vanadium(I) are inactive, but it was not known whether the active form contains vanadium at $+2,+3$, or +4 oxidation state [27]. It is now assumed that the active center is formed as a result of vanadium(IV) or vanadium(V) reduction in the precursor to vanadium(III). Organoaluminum compounds are used as the reducing agents [10]. Amongst disadvantages of vanadium catalysts are easy reduction to the inactive form of vanadium(II) [8-10], V-C bonding instability [28], and paramagnetic oxidation states (II, III and IV). To overcome a problem of deactivation, so-called reactivators are applied such as ETA (ethyl trichloroacetate, $\mathrm{Cl}_{3} \mathrm{CCOOEt}$ ) and chlorinated hydrocarbons 
(e.g. butyl perchlorocrotonate). To extend the catalyst life, auxiliary bidentate, tridentate or polydentate ligands with a stabilizing effect on the active center of vanadium are synthesized $[9,11,18]$.

The plastics market is constantly interested in new materials with specific, designed properties. Cyclic olefin/cycloolefin copolymers (COCs) are of particular interest. The most versatile and common COCs are ethylene-norbornene copolymers (Et-NB). These promising group of materials can be high-crystalline solids or thermoplastic elastomers depending on the degree of incorporation of norbornene and copolymer microstructure [29-31]. The Et-NB copolymers are used, among others, as materials in medical and diagnostic equipment, electronic devices, or as packaging films [29, 32-34].

To obtain such polymers with specific properties, many studies were devoted to the search for highly active catalysts, and thus, attention was also paid to organometallic vanadium-based complexes. Most literature reports concern the Et-NB copolymerization using: (i) catalysts with group 4 metals, usually $\mathrm{Ti}$ and $\mathrm{Zr}$, such as metallocenes, semi-metallocenes, and postmetallocenes, e.g. titanium complexes with phenoxyimine ligand [32, 35-37], (ii) transition metal complexes, primarily $\mathrm{Ni}$ and $\mathrm{Pd}$, with extended ligands of the type [NO], [NN] [38-41] and phosphorosulfonate [42-44], and (iii) rare earth complexes, especially scandium $[45,46]$. In contrast, the vanadium catalysts are less popular and still few have been used.

The aim of the study is to summarize the most important information on vanadium compounds used for the synthesis of Et-NB copolymers. It should be noted that so far no such review has been published. This work pre- sents the impact of various types of vanadium catalysts and reaction conditions on the copolymerization of ethylene with norbornene as well as the microstructure and selected properties of the obtained copolymers.

\section{PHOSPHINE LIGANDS}

Phosphine ligands are one of the most important group in organometallic chemistry [47, 48]. The synthesis, structure and reactivity of transition metal complexes with phosphines are studied because such complexes are able to catalyze various types of reactions [49-51]. Phosphine ligands can contain both alkyl and aryl groups, so that their steric and electronic properties can be tailored to specific applications. In addition, the relatively low cost and large variety of phosphines encourage the development of metal-phosphine complexes. The vanadium(III) (I-VII) and vanadium(IV) (VIII-X) catalysts with phosphine ligands used in the Et-NB copolymerization are complexes with monodentate and bidentate ligands [30, 52-54].

Substituents in the ligands are alkyl (methyl, ethyl, $t$-butyl) or cycloalkyl (cyclohexyl) and aryl (phenyl) groups. As standard, the copolymerization reactions is carried out in toluene, at temperature $20^{\circ} \mathrm{C}$, under ethylene pressure $0.1 \mathrm{MPa}$, with initial $\mathrm{NB}$ concentration 0.1-8.0 mol/ $\mathrm{dm}^{3}$, using $\mathrm{Et}_{2} \mathrm{AlCl}$ activator and ETA reactivator. The studied phosphine vanadium complexes are inactive in the homopolymerization of norbornene and reveal low active in the homopolymerization of ethylene. However, each of them proves to be highly active in the Et-NB copolymerization. This specific behavior<smiles>ClC1(Cl)P(c2ccccc2)(c2ccccc2)(c2ccccc2)CCP1(c1ccccc1)(c1ccccc1)c1ccccc1</smiles><smiles>[R][R]1([R])CCP([R])([R])(Cl)C1(Cl)Cl</smiles>

(II)<smiles>Cl[V](Cl)(Cl)(c1ccccc1)[PH](c1ccccc1)(c1ccccc1)c1ccccc1</smiles>

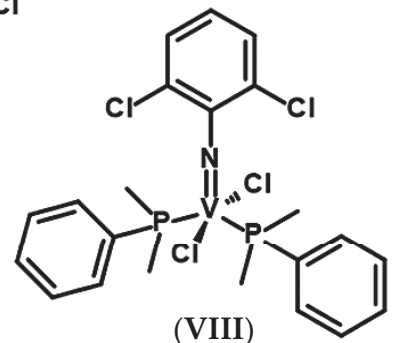<smiles>Cl[V](Cl)(Cl)(C1CCCCC1)P(C1CCCCC1)C1CCCCC1</smiles><smiles></smiles>

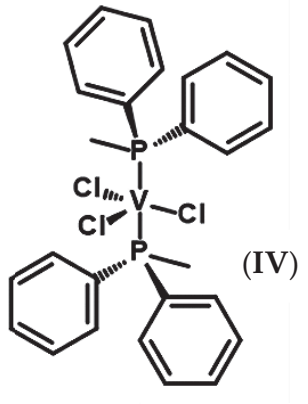<smiles></smiles>

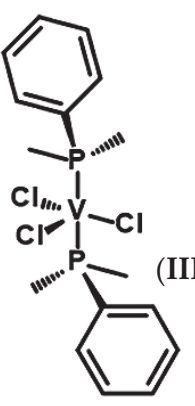

(III)

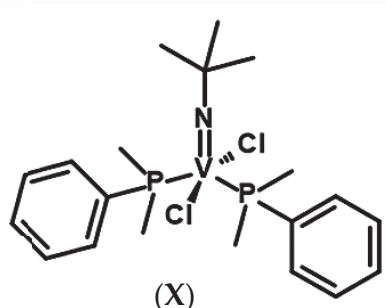


T a b l e 1. Results of ethylene-norbornene copolymerization

\begin{tabular}{|c|c|c|c|c|c|c|c|c|}
\hline Item & Complex & $\begin{array}{l}\text { NB feed } \\
\mathrm{mol} / \mathrm{dm}^{3}\end{array}$ & Activator & $\begin{array}{c}\text { Activity } \\
\mathrm{kg}_{\text {polym }} / \mathrm{mol}_{\mathrm{V}} \cdot \mathrm{h}\end{array}$ & $\begin{array}{c}\text { NB incorp. } \\
\mathrm{mol} \%\end{array}$ & $M_{w} \cdot 10^{-3}$ & $M_{w} / M_{n}$ & Ref. \\
\hline 1 & I & 0.6 & $\mathrm{Et}_{2} \mathrm{AlCl}$ & 16800 & 39.2 & 81.9 & 4.7 & [53] \\
\hline 2 & IV & 0.9 & $\mathrm{Et}_{2} \mathrm{AlCl}$ & 2976 & 43.7 & 17.6 & 2.2 & [30] \\
\hline 3 & $x$ & 8.0 & $\mathrm{Et}_{2} \mathrm{AlCl}$ & 109 & 39.3 & 178.0 & 2.1 & [52] \\
\hline 4 & XXIIIa & 0.5 & $\mathrm{Et}_{2} \mathrm{AlCl}$ & 49900 & 9.4 & 91.0 & 1.7 & [68] \\
\hline 5 & $x X$ & 3.0 & MAO & 163 & 45.3 & 36.3 & 1.9 & [65] \\
\hline 6 & XIX & 0.5 & $\mathrm{Me}_{2} \mathrm{AlCl}$ & 15900 & - & 9460.0 & 2.8 & [53] \\
\hline 7 & $X X X a$ & 0.5 & $\mathrm{Et}_{2} \mathrm{AlCl}$ & 329000 & 18.0 & 198.0 & 2.1 & [70] \\
\hline 8 & $\mathrm{XXXVb}$ & 3.0 & $\mathrm{Et}_{2} \mathrm{AlCl}$ & 5400 & 41.5 & 12.8 & 1.5 & [71] \\
\hline 9 & XXXVIII & 0.5 & $\mathrm{Me}_{2} \mathrm{AlCl}$ & 11640 & 15.5 & 879.9 & 2.9 & [72] \\
\hline 10 & XLIX & 0.5 & $\mathrm{Et}_{2} \mathrm{AlCl}$ & 16200 & 36.1 & 71.0 & 1.6 & [81] \\
\hline 11 & XLIX & 2.0 & $\mathrm{Et}_{2} \mathrm{AlCl}$ & 6200 & 48.2 & 49.0 & 1.6 & [81] \\
\hline 12 & XLII & 0.5 & $\mathrm{Et}_{2} \mathrm{AlCl}$ & 6480 & 32.6 & 157.0 & 1.6 & [80] \\
\hline 13 & LXV & 0.5 & $\mathrm{Et}_{2} \mathrm{AlCl}$ & 17300 & 37.7 & 57.2 & 2.0 & [94] \\
\hline 14 & LXIII & 0.9 & $\mathrm{Et}_{2} \mathrm{AlCl}$ & 7680 & 42.8 & 22.0 & 2.1 & [94] \\
\hline 15 & LXIX & 1.5 & $\mathrm{Et}_{2} \mathrm{AlCl}$ & 5296 & 27.5 & 180.0 & 1.9 & [98] \\
\hline 16 & LXVII & 1.5 & $\mathrm{Et}_{2} \mathrm{AlCl}$ & 1820 & 31.8 & 107.0 & 2.3 & [97] \\
\hline 17 & LXVIII & 0.5 & $\mathrm{EtAlCl}_{2}$ & 2155 & 17.4 & 762.0 & 1.6 & [97] \\
\hline 18 & LXVIII* & 0.5 & $\mathrm{Et}_{2} \mathrm{AlCl}$ & 7135 & 18.5 & 826.0 & 2.1 & [97] \\
\hline 19 & LXVII* & 1.5 & $\mathrm{EtAlCl}_{2}$ & 735 & 40.1 & - & - & [97] \\
\hline 20 & LXVIII* & 0.5 & EtAlCl${ }_{2}$ & 3660 & 20.1 & 960.0 & 2.0 & [97] \\
\hline 21 & LXXIII & 0.6 & $\mathrm{Et}_{2} \mathrm{AlCl}$ & 28440 & 41.2 & 43.6 & 4.4 & [53] \\
\hline 22 & LXXIII & 0.9 & $\mathrm{Et}_{2} \mathrm{AlCl}$ & 3840 & 45.7 & 9.0 & 2.1 & [30] \\
\hline 23 & LXXII* & 0.1 & $\mathrm{Et}_{2} \mathrm{AlCl}$ & 1660 & 3.5 & 879.0 & 1.6 & [82] \\
\hline
\end{tabular}

* SIL system

is explained by the coordination of the strongly nucleophilic and sterically large NB molecule, which stabilizes the active center, which in turn increases the propagation rate [55]. Moreover, the catalysts activity increases with the increase in the $\mathrm{Et}_{2} \mathrm{AlCl}$ amount and the $\mathrm{NB}$ initial concentration in the reaction environment [56]. Among the studied catalysts, the bidentate compound (I) is the most active [53]. At the NB initial concentration of $0.6 \mathrm{~mol} / \mathrm{dm}^{3}$, the activity of $16800 \mathrm{~kg} / \mathrm{mol}_{\mathrm{V}} \cdot \mathrm{h}$ is obtained (Table 1, item 1).

It should be noted that the copolymerization reaction is carried out for only 10 seconds. In the case of bidentate bimetallic catalysts (IIa, IIb) [53], activity decreases significantly, but still remains at a fairly high level of the order of several thousands $\mathrm{kg} / \mathrm{mol}_{\mathrm{V}} \cdot \mathrm{h}$. Vanadium monodentate complexes (III-VII) [54] show low or moderate activity. Among them, the complexes with arylphosphines (III-V) [54] are better than complexes with alkylphosphines (VI, VII) [54]. It can be observed that the more phenyl groups are in the phosphine environment, the higher activity is obtained. This means that the presence of the phenyl groups in the ligand improves catalytic activity by withdrawing electrons from the active center. It is noteworthy that vanadium(III) catalysts con- taining two phosphine groups (I-IV) are much less active than vanadium(IV) analogues (VIII-X).

The Nomura team first noted that the introduction of electron withdrawing substituents leads to more efficient incorporation of norbornene into the polymer chain [57]. The degree of NB incorporation is in the range of 7-46 $\mathrm{mol} \%$ and directly proportionate on its initial concentration (Table 1, item 2), but do not depend on the catalyst structure or vanadium oxidation state. The highest molecular weight $\left(M_{w}\right)$, up to $1.8 \cdot 10^{5} \mathrm{~g} / \mathrm{mol}$ (Table 1 , item 3) is obtained using the phosphine catalysts with additional imide ligand (VIII-X) [52]. The $M_{w}$ value is smaller when the complex contains bidentate phosphine ligands and the smallest when only monodentate ligands are present. The higher the initial NB concentration, the higher the copolymers $M_{w}$, which means that the coordination of norbornene slows down chain end reactions by limiting the chain transfer reaction for stereoelectronic reasons [56]. Most copolymers showed a monomodal and relatively narrow molecular weight distribution $\left(M_{w} / M_{n}\right)$ in the range of 1.8 to 7.0. The highest $M_{w} / M_{n}$ values show copolymers obtained with using the vanadium catalysts having alkylphosphine ligands (VI, VII) [54]. The vanadium(IV) complexes (VIII-X) show larger $M_{w}$ and 
often narrower $M_{w} / M_{n}$ than the vanadium(III) analogues (I-VII). The values of glass transition temperature $\left(T_{q}\right)$ are from 0 to $101^{\circ} \mathrm{C}$ for $40 \mathrm{~mol} \% \mathrm{NB}$ incorporation and increases proportionally with the increase of NB content, suggesting that the obtained product has uniformly incorporated comonomer units.

\section{IMIDO LIGANDS}

In recent years, a lot of attention has been paid to ligands with electron-donor nitrogen atoms $[58,59]$. This group includes imido complexes of transition metals, which aroused particular interest due to their metallocene-like activity in copolymerization reactions and the possibility of selecting steric and electronic properties by changing substituents $[60,61]$. Formulas (XI-XXIV) present vanadium $(\mathrm{V})$ catalysts with imido ligands, which have been used in the Et-NB copolymerization [62-67].
The imido ligands contain mainly aryl substituents, but in addition, imidazoline-2-imine (XI-XVI) [62, 63], imidazolidine-2-imine (XVII, XVIII) [62], 2-benzimidazolopyridine (XIX) [64] or aryloxy ligand (XX-XXIV) [65-67] in which alkyl, aryl, or halogen atoms are substituents. This type of complexes are activated with various types of organoaluminum compounds ( $\mathrm{Et}_{2} \mathrm{AlCl}, \mathrm{Me}_{2} \mathrm{AlCl}$, $\mathrm{MAO}$-methylaluminoxane). Copolymerization reactions are carried out in toluene, at temperature 0 or $25^{\circ} \mathrm{C}$, at ethylene pressure $0.8 \mathrm{MPa}$, with initial $\mathrm{NB}$ concentration 0.1-5.0 $\mathrm{mol} / \mathrm{dm}^{3}$. The complex (XXIIIa) [68] with fluorine atoms at the positions 2 and 6 in the aromatic ring of the arylimido ligand is the most active. It shows the activity of $49000 \mathrm{~kg} / \mathrm{mol}_{\mathrm{V}} \cdot \mathrm{h}$ at the initial NB concentration of $0.5 \mathrm{~mol} / \mathrm{dm}^{3}$, temperature $25^{\circ} \mathrm{C}$, and $\mathrm{Et}_{2} \mathrm{AlCl}$ activator (Table 1, item 4). Similar results are obtained for complexes (XXIIIb, XXIVa, XXIVb) [68], and (XX-XXII) $[65,66]$. It can be concluded that the catalytic activity of<smiles>Cc1cccc(C)c1N=[W](Cl)(Cl)N=c1n(C(C)(C)C)ccn1C(C)(C)C</smiles><smiles>Cc1cccc(C)c1-n1ccn(-c2c(C)cccc2C)c1=NN=C(Cl)Cl</smiles>

(XII)<smiles>CC(C)c1cccc(C(C)C)c1-n1ccn(-c2c(C(C)C)cccc2C(C)C)c1=NN(Cl)c1ccccc1</smiles>
$(\mathrm{XV})$

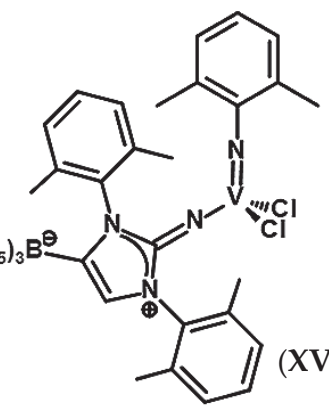
$(\mathrm{XVI})$

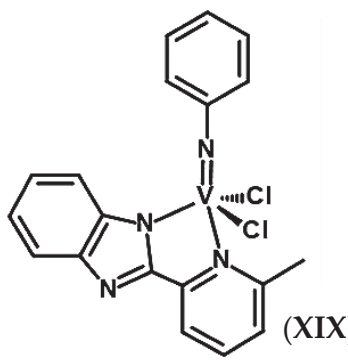<smiles>Cc1cccc(C)c1N=[V](Cl)(Cl)Oc1c(C)cccc1C(=O)O</smiles><smiles>Cc1cccc2c1N=[W](Cl)(Cl)Oc1c(cccc1-c1ccc(OC(C)(C)C)cc1)Cc1cccc-2c1</smiles><smiles></smiles>

(XXIII)<smiles>[R]c1cccc([R])c1O[V](Cl)(Cl)=Nc1c(F)cccc1N=[V](Cl)(Cl)=Nc1c(C)cccc1C</smiles><smiles>Cc1cccc(C)c1N=[W](Cl)(Cl)N=c1n(-c2c(C)cccc2C(C)C)ccn1-c1c(C(C)C)cccc1C(C)C</smiles><smiles>Cc1cccc(C)c1N=[W](Cl)(Cl)N=C1N(c2c(C(C)C)cccc2C(C)C)CCN1c1c(C(C)C)cccc1C(C)C</smiles>

(XXIV) 
arylimide complexes increases significantly if the aryloxy ligand is also present. Moreover, the introduction of halogen $(\mathrm{Cl}, \mathrm{F})$ at the position 2 and 6 of the arylimido ligand (XXIII, XXIV) [65] effectively increases the catalyst activity. Lower activities are obtained using the complex (XIX) [64] activated by $\mathrm{Me}_{2} \mathrm{AlCl}$ with 2-(2-pyridinyl)-benzimidazole bidentate ligand (23 $\left.700 \mathrm{~kg} / \mathrm{mol}_{\mathrm{V}} \cdot \mathrm{h}\right)$. Satisfactory activities are obtained with complexes containing monodentate ligands, without aryloxy group. Among them, the highest catalytic activity $\left(14800 \mathrm{~kg} / \mathrm{mol}_{\mathrm{V}} \cdot \mathrm{h}\right)$ is obtained using the complex (XVI) [63] containing in its structure tris(pentafluorophenyl)borate as substituent at the imidazoline-2-imine ligand and activated by $i$ - $\mathrm{Bu}_{3} \mathrm{Al}$. It can be seen that the use of a large substituent at the imidazoline-2-imine ligand increases the catalytic activity of the complex, while no such relationship is observed when the structure of the imido ligand is changed. The initial NB concentration has a great influence on the catalytic activity of imido complexes. Initially, the activity increases in the range of $0.1-0.5 \mathrm{~mol} / \mathrm{dm}^{3} \mathrm{NB}$, however, a further increase of the NB concentration in the reaction medium leads to its decrease. The type of activator is also an important factor for the catalytic activity of vanadium complexes. Using the complex (XX) [66], the effect of an organoaluminum compound on the catalyst efficiency was investigated. It was found that catalytic activity increases in the order of activators: $\mathrm{Et}_{2} \mathrm{AlCl}>\mathrm{iBu}_{2} \mathrm{AlCl}$ $>\mathrm{Me}_{2} \mathrm{AlCl}>\mathrm{MAO}>\mathrm{EtAlCl}_{2}$. The degree of incorporation of norbornene units in the copolymer chain depends on the initial NB concentration and the type of activator, and ranges from $5 \mathrm{~mol} \%$ for very low initial NB concentrations up to $45 \mathrm{~mol} \%$ (Table 1, item 5). The use of MAO activator instead of $\mathrm{Et}_{2} \mathrm{AlCl}$ allows to obtain copolymers with much higher NB content. Copolymerization performed in toluene using the complex (XX) [66] shows that the NB content in copolymers depends on the type of organoaluminum activator in the order: $\mathrm{MAO}>\mathrm{Me}_{2} \mathrm{AlCl}>\mathrm{iBu}_{2} \mathrm{AlCl}$, Et $\mathrm{AlCl}_{2}>\mathrm{Et}_{2} \mathrm{AlCl}$. In the same conditions, the vanadium catalyst structure does not significantly affect the degree of comonomer incorporation. When the structure of the ligands is changed, no difference in the NB content in the copolymers is observed. This indicates that the organoaluminum compound has the greatest impact on the monomer reactivity in the Et-NB copolymerization.

The highest molecular weight up to $9.5 \cdot 10^{6} \mathrm{~g} / \mathrm{mol}$ (Table 1, item 6) is obtained using the vanadium complex with imido ligand and 2-benzimidazolopyridine (XIX) [64]. The complexes with arylimido and aryloxy ligands (XXIII, XXIV) [65] give products with low $M_{w^{\prime}}$ especially arylimido complexes with imidazoline-2-imine ligand substituted with tris(pentafluorophenyl)borate (XVI) [63]. Generally, the copolymers $M_{w}$ increases with the increase of the initial NB concentration. All obtained Et-NB copolymers are characterized by a narrow, monomodal molecular weight distribution (1.2-3.3), regardless of the vanadium complex or the type of activator. The $T_{g}$ values (from -6 to $83^{\circ} \mathrm{C}$ ) determined only for a few selected copolymers increase linearly with the increase of NB content in the copolymer.

\section{AMINE LIGANDS}

The vanadium complexes with amine ligands used in the ethylene-norbornene copolymerization contained the following ligands: amino alcoxy (XXV, XXVI) [69], aminopyridino phenolate (XXVII-XXXI) [70], aminopyridino bis(phenolate) (XXXII-XXXV) [71], amino bis(phenolate) (XXXVI, XXXVII) [69], amino bis(benzimidazole) (XXXVIII, XXXIX) [72], and diamino bis(phenolate) (XL) $[72,73]$.

In these compounds, the vanadium(V) is present, except (XXXVIII) and (XL) with vanadium(III) and (XXXIX) with vanadium(IV).

The Et-NB copolymerization reactions with using these complexes are usually carried out in toluene, at temperature range $25-60^{\circ} \mathrm{C}$, ethylene pressure 0.05 or $0.6 \mathrm{MPa}, \mathrm{NB}$ initial concentration from 0.1 to $3.0 \mathrm{~mol} / \mathrm{dm}^{3}$ and, using $\mathrm{Et}_{2} \mathrm{AlCl}, \mathrm{EtAlCl}_{2}$, or $\mathrm{Me}_{2} \mathrm{AlCl}$ activators, and ETA reactivator. These catalysts are active both in ethylene homopolymerization and Et-NB copolymerization, however, they often show higher activity in the copolymerization. The catalysts containing the aminopyridino phenolate ligand are very active. The best results, up to $329000 \mathrm{~kg} / \mathrm{mol}_{\mathrm{v}} \cdot \mathrm{h}$ (Table 1, item 7) are obtained using the complex (XXXa) [70] activated by $\mathrm{Et}_{2} \mathrm{AlCl}$, at the activator/catalyst molar ratio $\mathrm{Al} / \mathrm{V}=6000$. An additional phenolate group in the ligand (XXXII-XXXV) [71] decreases activity. The activities observed for the complexes with amino bis(benzimidazole) ligands (XXXVIII, XXXIX) [72] and amino ligands containing phenolate groups (XXVI, XXXVI, XXXVII) [69] are comparable. The lowest activity is obtained using the vanadium complex with a diamino bis(phenolate) ligand (XL) [73, 74]. In summary, the catalysts performance decreases in the order of ligands: aminopyridino phenolate $>$ amino bis(benzimidazole) $>$ amino bis(phenolate) $>$ diamino bis(phenolate). There are some recurring trends in a given group of amine catalysts. Higher catalytic activities are achieved if at least two aromatic rings with a methoxy substituent are present in the complex. The activity is much lower when: (i) the aromatic ring is substituted only with alkyl groups, (ii) there is only one aromatic ring in the structure. Similar results are obtained for the bimetallic vanadium complexes. Comparing the effect of the type of active center, it can be seen that vanadium(V) and vanadium(IV) complexes show similar activity while vanadium(III) gives slightly smaller amounts of the product. The initial NB concentration in the reaction medium also affects the catalytic activity. At low NB concentration (up to 0.5 $\left.\mathrm{mol} / \mathrm{dm}^{3}\right)$, the activity of vanadium catalysts increases, but further increase of the NB concentration results in decrease of catalyst activity. The degree of incorporation of norbornene unit into the copolymer chain depends primarily on the initial NB concentration from $5 \mathrm{~mol} \%$ to 42 


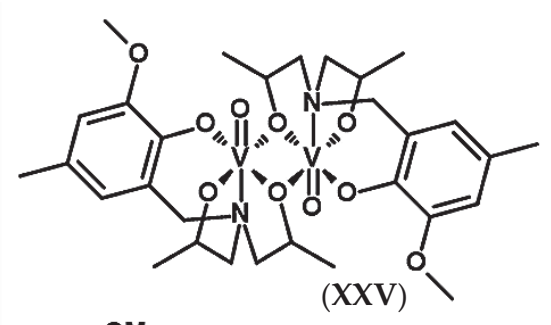

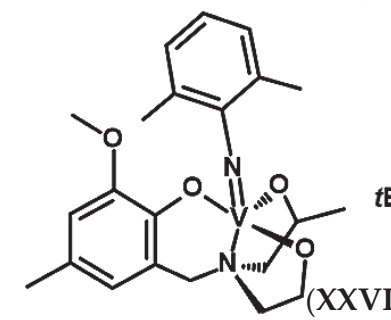

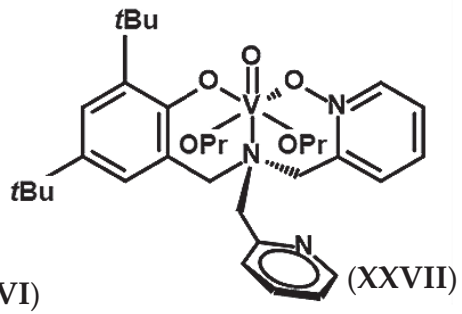<smiles></smiles>

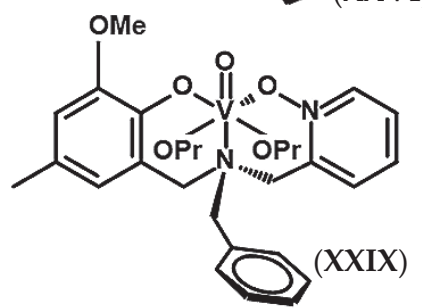

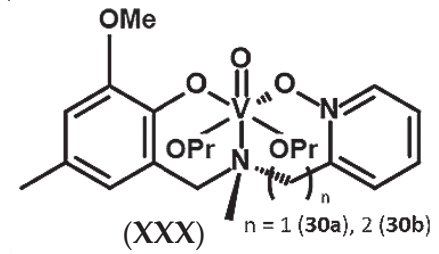

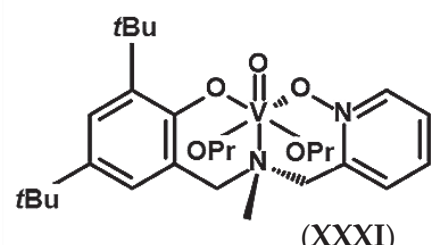

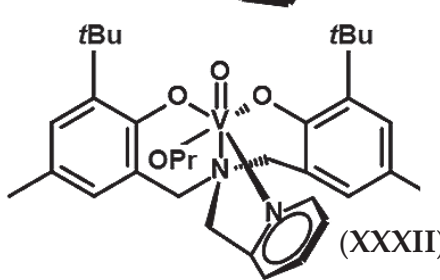

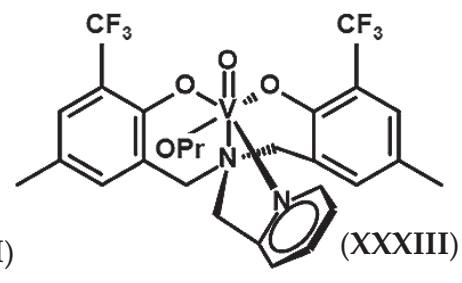

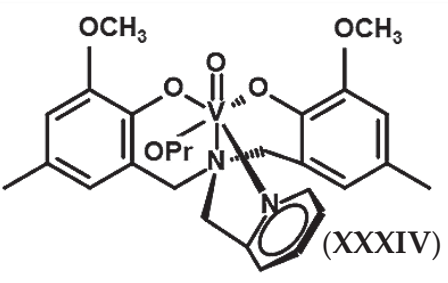

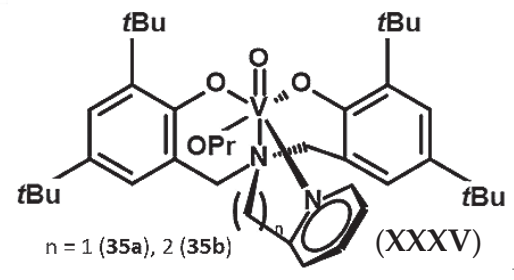

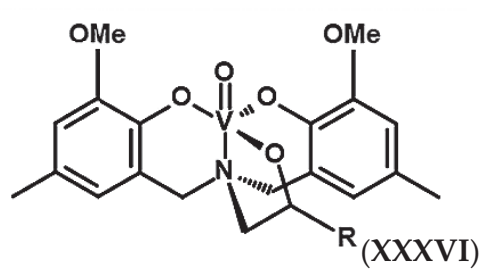<smiles>Cc1cc(C)c(N2CC3(C)CN2Cc2cc(C)cc(C)c2O3)c(C)c1</smiles>

(XXXVII)<smiles>CN(Cc1nc2ccccc2[nH]1)Cc1nc2ccccc2n1CC(O)(Cl)Cl</smiles><smiles></smiles>



$\mathrm{mol} \%$ (Table 1, item 8). The highest ability to incorporate comonomer units show the vanadium amine complexes with the aminopyridine bis(phenolate) ligand, among them the complex $(\mathbf{X X X V b )}$ [71]. Considering oxidation state, at a low NB initial concentration the highest comonomer incorporation give the vanadium(IV) complexes while the smallest those of vanadium(III).

The highest molecular weight, up to $8.8 \cdot 10^{5} \mathrm{~g} / \mathrm{mol}$ (Table 1, item 9) is obtained using the catalyst (XXXVIII) [72] activated by $\mathrm{Me}_{2} \mathrm{AlCl}$, with an additional amino bis(benzimidazole) ligand. Other catalysts activated with $\mathrm{Et}_{2} \mathrm{AlCl}$ allow obtaining the polymers having $4-5$ times lower molecular weights. In case of the complexes containing pyridinium and phenolate ligands (XXVII-XXXV) $[70,71]$ the increase of the initial NB concentration up to $0.7 \mathrm{~mol} / \mathrm{dm}^{3}$ results in the increase of molecular weights, however, after exceeding this value the $M_{w}$ decreases. In contrast, in case of the aminophenolate complexes ( XXV, XXVI, XXXVI, XXXVII) [69] a decrease in the copolymers $M_{w}$ is observed with an increase in the NB amount in the reaction mixture. All obtained copolymers show monomodal and narrow $M_{w} / M_{n}$ in the range from 1.5 to 2.9, which indicates the homogeneity of active centers. The vanadium(IV) complexes give polymers with higher molecular weight and broader $M_{w} / M_{n^{\prime}}$ as compared to vanadium(III) and vanadium(V).

\section{$\beta$-ENAMINOKETONATO LIGANDS}

Thanks to the possibility of extensive structure modification, $\beta$-enaminoketonato ligands are a good material for design of transition metal complexes. The titanium catalysts, obtained with this type of unsymmetrical bidentate ligands, have proved to be very active not only in the 
polymerization of ethylene, but also in the copolymerization of ethylene with $\alpha$-olefins or cycloolefins [75-79]. In the Et-NB copolymerization, a series of the vanadium complexes were tested with $\beta$-enaminoketonato ligands having unconstrained (XLI-XLVI) $[9,80]$ or constrained cyclic (XLVII-LX) [9, 81-84] structure, containing aromatic, aliphatic, or perfluorinated groups as substituents.

In these compounds, the vanadium(V) is present, except (LII) with vanadium(IV). In addition, the catalyst (LII) was also tested in a form of heterogeneous SIL (Supported Ionic Liquid) system, in which the vanadium compound is placed in a thin layer of pyridinium ionic liquid [82]. Reactions with these complexes are carried out in toluene or hexane, at temperatures 25,30 or $50^{\circ} \mathrm{C}$, ethylene pressure 0.1 or $0.5 \mathrm{MPa}$, initial $\mathrm{NB}$ concentration from 0.05 to $2.0 \mathrm{~mol} / \mathrm{dm}^{3}$, Et $\mathrm{AlCl}$ activator and ETA reactivator. The complex (LVIII) [84] (29500 kg/mol $/ \mathrm{h}$, Table 1, item 10) with the cyclic, 10 -carbon $\beta$-enaminoketonato ligand bond with vanadium center via $\mathrm{O}, \mathrm{N}$ and $\mathrm{S}$ donor is the most active among the tested catalysts. Expanding the ligand by increasing the number of carbon atoms in the cyclic part reduces the effectiveness of polyreaction. The cyclic structure of $\beta$-enaminoketonato ligands limits rotation of substituents in ortho position in relation to the oxygen atom, which increases steric hindrance and thus improves stability and catalytic activity. Among the catalysts with the unconstrained structure of $\beta$-enaminoketonato ligand, the most active is the complex (XLV) [80]. The catalyst (XLIV) [80] with an additional methyl substituent is slightly less efficient. The substitu-<smiles></smiles>

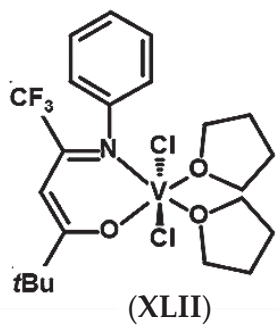<smiles>CC1=CC(C(F)(F)F)O[C@@](Cl)(O[C@]2(Cl)OCCC23CCCC3)N1c1ccccc1</smiles><smiles>CC1=CC(c2ccccc2)OC(Cl)(OC2(Cl)OCCC23CCCC3)N=C(C)c2ccccc21</smiles>

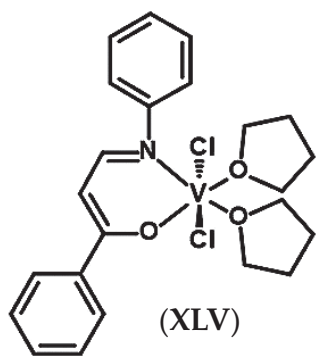

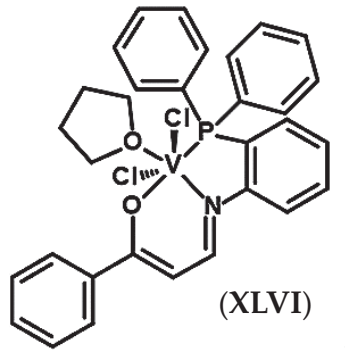

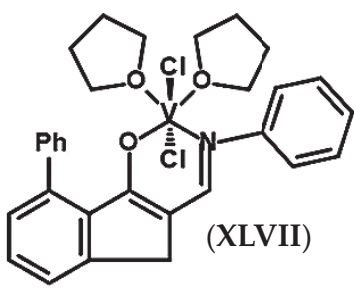

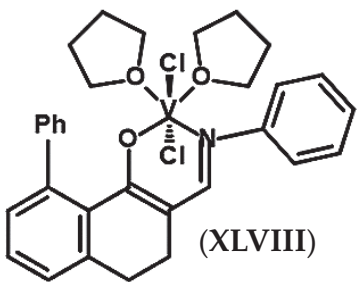

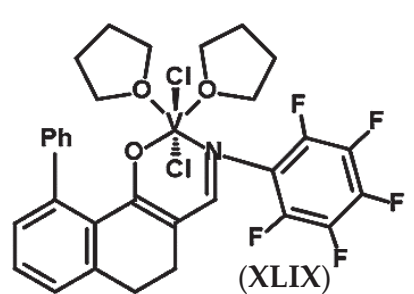

<smiles>CC1(Cl)CCC2=C(O1)C1=C(CCC2)c2cccc(-c3ccccc3)c21</smiles>

$(\mathrm{L})$<smiles>c1ccc(C2CCCC2)cc1</smiles><smiles></smiles>

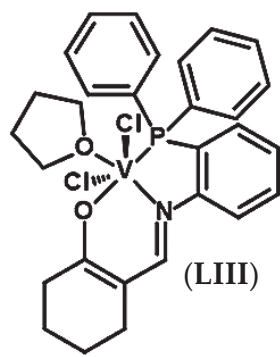

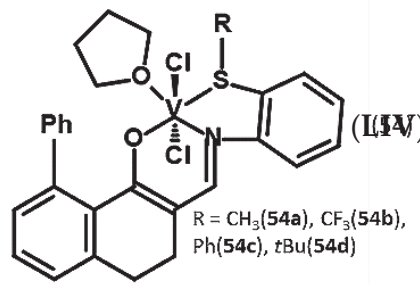

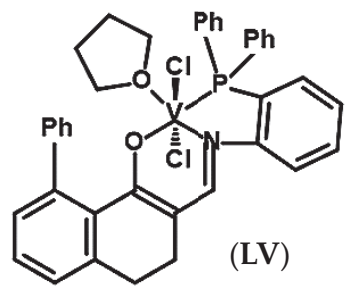<smiles>CC1(Oc2ccccc2-c2ccccc2)C=C2CCc3cccc(-c4ccccc4)c3C2(OC2CCCC2)O1</smiles>

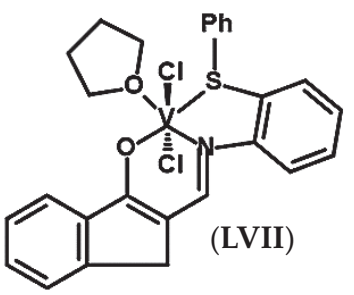

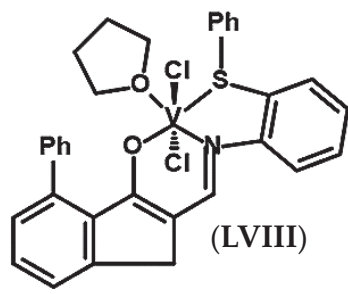

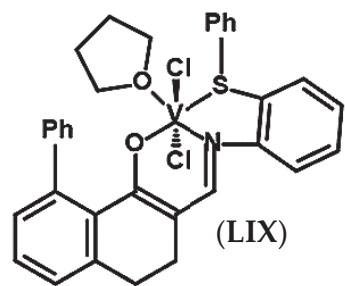

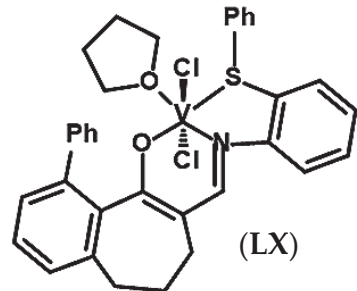


tion of methyl by trifluoromethyl group (XLI-XLIII) [80] does not bring a positive effect. In contrast, the substitution of hydrogen atoms of the phenyl group with fluorine atoms at the nitrogen atom of $\beta$-enaminoketonato ligands (XLVIII, XLIX) [81] improves the copolymerization efficiency. The heterogeneous SIL system shows greater stability and is more active in copolymerization [82]. For all homogeneous and heterogeneous vanadium catalysts with $\beta$-enaminoketonato ligand, the catalytic activity decreases with the increase of the initial NB concentration in the reaction mixture. The increase of temperature from 25 to $50^{\circ} \mathrm{C}$ allows obtaining higher amount of the polymer product. The degree of norbornene incorporation into the copolymer chain is very high, from about 27 to over $48 \mathrm{~mol} \%$ (Table 1, item 11) and strictly depends on the initial NB concentration. The increase of temperature also has an advantageous effect on the commoner content. Under similar conditions, the catalyst with $\beta$-enaminoketonato ligand with the cyclic structure shows a slightly higher ability to incorporate norbornene units, while the vanadium(IV) catalyst deals with this worse compared to vanadium(III).

The highest molecular weight up to $1.6 \cdot 10^{5} \mathrm{~g} / \mathrm{mol}$ (Table 1, item 12) is obtained using the catalysts with unconstrained $\beta$-enaminoketonato ligand substituted with methyl and phenyl groups (XLIV) [80]. Generally, the complexes with unconstrained ligands allow obtaining much larger macromolecules than the constrained cyclic analogues. Heterogenization of catalysts results in the increase of the copolymers $M_{w}$ value. The increase of temperature has opposite effect. The copolymers $M_{w} / M_{n}$ value is monomodal and narrow (from 1.3 to 2.1). Slightly higher $M_{w} / M_{n}$ values can be obtained using the catalysts with constrained $\beta$-enaminoketonatol ligand or using the vanadium(IV) complex instead of vanadium(III) analogues. The glass transition temperatures $\left(67-115^{\circ} \mathrm{C}\right)$ of the obtained copolymers increase proportionally with the increase of NB content, which indicates a uniform comonomer incorporation.

\section{SALICYLALDIMINATO LIGANDS}

It is known that the catalytic activity and/or selectivity of catalysts with metal atom belonging to group 4 increases after the introduction of ligands with donor atoms, like oxygen and nitrogen. It is explained by spatial hindrance and electron effects that stabilize the catalyst active center [85-92]. Vanadium(III) mono(salicylaldiminato) complexes undergo fast deactivation at high polymerization temperatures. The main reason for this phenomenon is the reduction of vanadium atom to a less active or inactive low oxidation state. This can be reduced by the increase of thermal stability of the catalysts, which is obtained by the introduction of an additional functional group containing heteroatom in the vanadium coordination sphere $[93,94]$. Among the vanadium catalysts with salicylaldiminato ligands used in the Et-NB copolymerization, there are compounds with $\pi$-donor heteroatoms such as O (LXI) [94], N (LXII-LXIV) [94], S (LXV) [94] and P (LXVI) [94].

Using the complexes (LXI-LXVI) [94], the copolymerization reactions are performed in toluene, at temperature of $50^{\circ} \mathrm{C}$, pressure of $0.1 \mathrm{MPa}$, initial NB concentration $0.1-0.9 \mathrm{~mol} / \mathrm{dm}^{3}$, using $\mathrm{Et}_{2} \mathrm{AlCl}$ activator and ETA reactivator. All investigated catalysts are active both in ethylene polymerization and Et-NB copolymerization. The most active in the Et-NB copolymerization is the vanadium(III) complex with the salicylaldiminato group and the electron donor phosphorus atom (LXVI) [94] (17 $300 \mathrm{~kg} / \mathrm{mol}_{\mathrm{v}} \cdot \mathrm{h}$, Table 1, item 13). Slightly lower results are obtained using the catalyst LXIII [94] with pyridine nitrogen substituent. The least effective is the
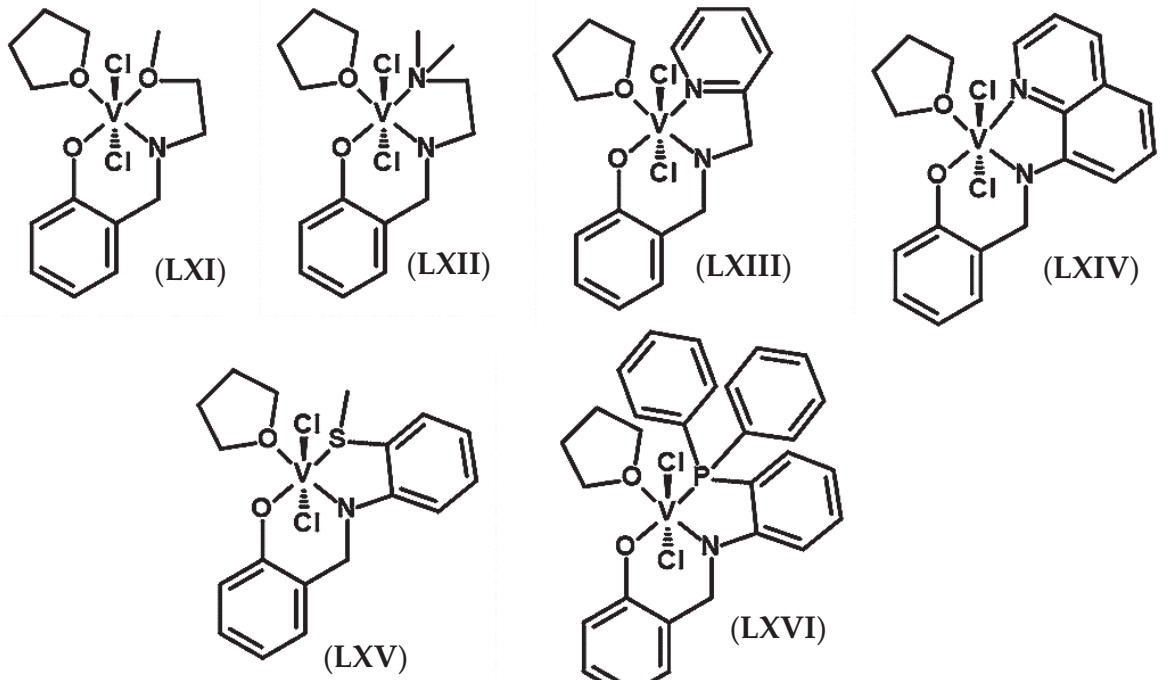

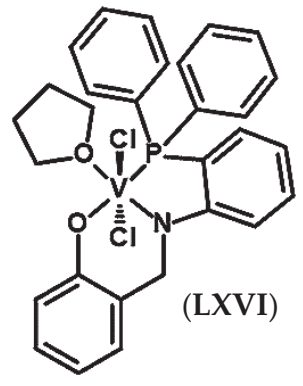


complex (LXI) [94] with the electron donor oxygen atom. This demonstrates the significant influence of the ligand donor atom on the catalytic activity. The initial NB concentration is also important; the higher amount of norbornene in reaction medium, the lower copolymerization yield is obtained. The degree of incorporation of norbornene into the copolymer chain (up to $43 \mathrm{~mol} \%$, Table 1 , item 14) does not depend essentially on the structure of complex, but it depends on the initial norbornene concentration.

The highest molecular weight $\left(5.7 \cdot 10^{4} \mathrm{~g} / \mathrm{mol}\right.$, Table 1, item 13) is obtained using the most active catalyst (LXVI) [92], with P atom. Other complexes produce macromolecules with comparable molecular weight. The $M_{w}$ values decrease with increasing the initial NB concentration and the amount of $\mathrm{Et}_{2} \mathrm{AlCl}$ activator. The molecular weight distribution for all products is monomodal and narrow (2.0 to 2.4), regardless of the complex used or the initial $\mathrm{NB}$ concentration. The glass transition temperature of the copolymers $\left(29-94^{\circ} \mathrm{C}\right)$ increases with the increase of NB content in the copolymer.

\section{OXAZOLINE AND OXAZINE LIGANDS}

Transition metal complexes with oxazoline or oxazine ligands are a promissing alternative to metallocene complexes used in copolymerization reactions of stereogenic polymers $[95,96]$. In the Et-NB copolymerization, the vanadium(III) complexes with pyridine oxazoline (LXVII) [97], pyridine bis(oxazoline) (PyBOX) (LXVIII) [97] and vanadium(IV) complexes with phenoxy oxazoline (LXIX, LXX) [98] and phenoxy oxazine (LXXI) [98] were studied.

In addition, the catalysts (LXVII, LXVII) [97] were also tested in heterogeneous SIL (Supported Ionic Liquid) systems, in which the vanadium compound is placed in a thin layer of pyridinium ionic liquid. Reactions are carried out in hexane, at temperature $30^{\circ} \mathrm{C}$, ethylene pressure $0.5 \mathrm{MPa}, \mathrm{NB}$ concentration $0.5-1.5 \mathrm{~mol} / \mathrm{dm}^{3}$, using $\mathrm{Et}_{2} \mathrm{AlCl}$ or $\mathrm{EtAlCl}_{2}$ activator and ETA reactivator. All of these complexes are active both in ethylene homopolymerization and Et-NB copolymerization. Among non-supported catalysts, the highest activity up to $5300 \mathrm{~kg} / \mathrm{mol}_{\mathrm{v}} \mathrm{h}$ is achieved by the complex LXIX [98] with phenoxy oxazoline ligand (Table 1, item 15) activated by $\mathrm{Et}_{2} \mathrm{AlCl}$. It should be noted, however, that the amount of product obtained using the complexes (LXVII, LXVIII, LXX, LXXI) [97, 98] with $\mathrm{Et}_{2} \mathrm{AlCl}$ is only slightly smaller. The least active compound is the complex (LXX) [98], which differs from the analogue (LXIX) [98] only with the presence of a methyl substituent at the oxazoline ring. Amongst the complexes (LXIX-LXXI) [98], in which there are two phenoxy oxazoline or phenoxy oxazine ligands at the active center, the most effective is the catalyst (LXIX) [98], in which the ligand impose the lowest steric crowding. On the other hand, when comparing catalysts with oxazolinepyridine (LXVII) [97] or bis(oxazoline) pyridine (LXVIII) [97] in the vanadium coordination sphere, the complex with the larger ligand (LXVIII) [97] is better. In general vanadium(IV) complexes show slightly higher activity in the Et-NB copolymerization. The heterogeneous SIL systems shows greater stability and thus higher activity in the copolymerization (Table 1, item 18). The $\mathrm{Et}_{2} \mathrm{AlCl}$ is much better activator than $\mathrm{EtAlCl}_{2}$, regardless of the type of catalyst used. For the complexes (LXIX-LXXI) [98], with phenoxy oxazoline or phenoxy oxazine ligands, the increase of initial NB concentration in the range 0.5$1.0 \mathrm{~mol} / \mathrm{dm}^{3}$ increases the catalysts activity, however, the activity decreases at higher NB concentration. When the catalysts (LXVII, LXVIII) [97] are used, both homogeneous and heterogeneous, the polyreaction efficiency rises, with the increase of the amount of NB in reaction medium. For the vanadium catalysts with oxazoline and oxazine ligands, the degree of incorporation of norbornene in the copolymer chain is in the range of $12-32 \mathrm{~mol} \%$ (Table 1, item 16). It depends not only on the amount of added NB, but also on the complex used, which is particularly evident at low initial NB concentration. The heterogeneous catalysts show better comonomer incorporation (Table 1, item 19).

The highest molecular weight (up to $7 \cdot 6 \cdot 10^{5} \mathrm{~g} / \mathrm{mol}$, Table 1. item 17) is obtained using the vanadium catalyst with pyridine bis(oxazoline) ligand (LXVIII) [97] and the lowest using the complex with phenoxy oxazoline ligand (LXX) [98]. Heterogenization of the catalysts allows obtaining copolymers with higher $M_{w}$ as compared to their

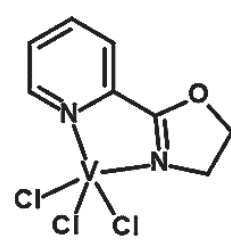

(LXVII)

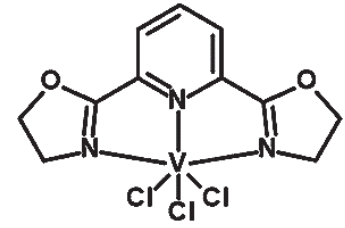

(LXVIII)

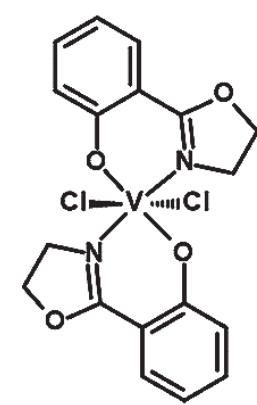

(LXIX)

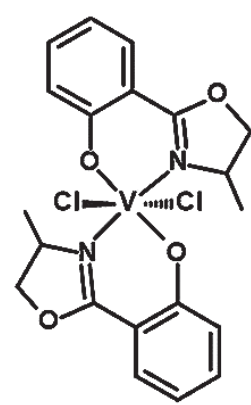

(LXX)

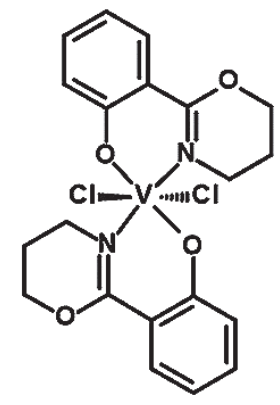

(LXXI) 
homogeneous analogues (Table 1, item 20). The type of organoaluminum compound used for the activation is also important, $\mathrm{EtAlCl}_{2}$ allows to obtain larger macromolecules than $\mathrm{Et}_{2} \mathrm{AlCl}$. The copolymer $M_{w}$ clearly decreases with increasing initial comonomer concentration. The products obtained with the use of homogeneous catalysts are characterized by a monomodal and narrow $M_{w} / M_{n}(1.6-2.3)$. Et-NB copolymers obtained with vanadium(III) complex are characterized by a higher molecular weight than the products of vanadium(IV) catalyst, but with a comparable molecular weight distribution. The glass transition temperature of the copolymers (from -3.2 to $62^{\circ} \mathrm{C}$ ) increases with increase of the degree of NB incorporation.

\section{MISCELLANEOUS}

Commercial complexes: $\mathrm{Cp}_{2} \mathrm{VCl}_{2}$ (LXXII) [82] and $\mathrm{VCl}_{3}(\mathrm{THF})_{3}$ (LXXIII) $[30,53]$ have also been used in the Et-NB copolymerization.

The $\mathrm{Cp}_{2} \mathrm{VCl}_{2}$ complex (LXXII) [82] was used as a homo-

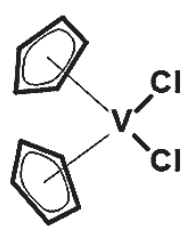

(LXXII)

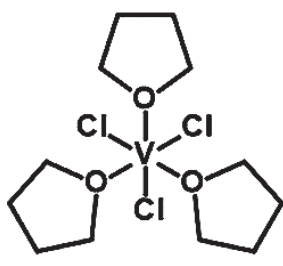

(LXXIII) geneous catalyst as well as in the form of SIL system. Reactions were carried out in hexane, at $30^{\circ} \mathrm{C}, 0.5 \mathrm{MPa}$, the initial $\mathrm{NB}$ concentration in the range from 0.05 to $1.5 \mathrm{~mol} / \mathrm{dm}^{3}$, with the $\mathrm{Et}_{2} \mathrm{AlCl}$ activator and the ETA reactivator. This complex proves to be active both in the ethylene polymerization and the Et-NB copolymerization. The highest activity $\left(6250 \mathrm{~kg} / \mathrm{mol}_{\mathrm{V}} \cdot \mathrm{h}\right)$ is achieved using the SIL system. The activity of homogeneous analogue is considerably lower. The NB incorporation rises with increase of the comonomer concentration in the reaction mixture, reaching the value of $30 \mathrm{~mol} \%$. In this case, better results are also achieved using the SIL systems. The increase of the NB concentration in the reaction medium results in the lower copolymer molecular weight. The highest $M_{w}\left(8.8 \cdot 10^{5} \mathrm{~g} /\right.$ mol; Table 1, item 23) has the polymer with low NB content. The molecular weight distribution ranges from 1.5 to 3.0.

Positive results in the Et-NB copolymerization are also obtained using the commercial complex $\mathrm{VCl}_{3}(\mathrm{THF})_{3}$ (LXXIII) [30, 53]. The reaction was carried out in the presence of $\mathrm{Et}_{2} \mathrm{AlCl}$ and ETA, in toluene, at $22^{\circ} \mathrm{C}$, under ethylene pressure $0.1 \mathrm{MPa}$, with the initial NB concentration $0.1-0.9 \mathrm{~mol} / \mathrm{dm}^{3}$. This complex proves to be relatively active in copolymerization (28 $440 \mathrm{~kg} / \mathrm{mol}_{\mathrm{V}} \cdot \mathrm{h}$, Table 1, item 21). However, $\mathrm{VCl}_{3}$ [30] used in similar conditions is completely inactive. The incorporation of NB units in the copolymer obtained using the $\mathrm{VCl}_{3}(\mathrm{THF})_{3}[30,52]$ complex rises with the increase of NB concentration in the reaction mixture, reaching the value of $46 \mathrm{~mol} \%$ (Table 1, item 22). The higher comonomer content in the polymer, the lower its molecular weight. The molecular weights distribution does not exceed 5.2. The $T_{g}$ values $\left(1-45^{\circ} \mathrm{C}\right)$ do not increase proportionally with the increase of NB content, which may indicate uneven comonomer incorporation.

\section{MICROSTRUCTURE OF ETHYLENE- NORBORNENE COPOLYMERS}

The microstructure of the copolymers obtained by vanadium catalysts with phosphine, imido, amine, $\beta$-enaminoketonato or salicylaldiminato ligands are comparable, regardless of the type of catalyst system. In ${ }^{13} \mathrm{C}$ NMR spectra, the dominant signals are from isolated and alternated norbornene units, as it is presented on schematic spectrum (Fig. 1). Even for polymer with a high comonomer content no diads or longer NB sequences are observed.

In contrast, the microstructures of copolymers obtained by vanadium catalysts with oxazoline or oxazine ligands depends on the NB incorporation. When it is less than $20 \mathrm{~mol} \%$ the NB incorporation is very similar, regardless of the type of vanadium complex. Only isolated and alternated NB units are found. At higher degree of NB incorporation, a clear effect of the type of catalyst on the copolymer microstructure is found. In the polymer obtained using the complexes LXVII-LXIX and LXXI [97, 98], diads and triads microblocks are observed, in addition to isolated and alternated NB units. Interestingly, the catalyst LXX [98] with a methyl substituted at phenoxy oxazoline ligand produces longer microblocks which leads to a product with triad sequences. In the case of $\mathrm{Cp}_{2} \mathrm{VCl}_{2}$ (LXXII) [82] only isolated units are observed for the smallest incorporation. Further increase of the comonomer content results in appearance of alternated and then diads and traces of triads microblocks.

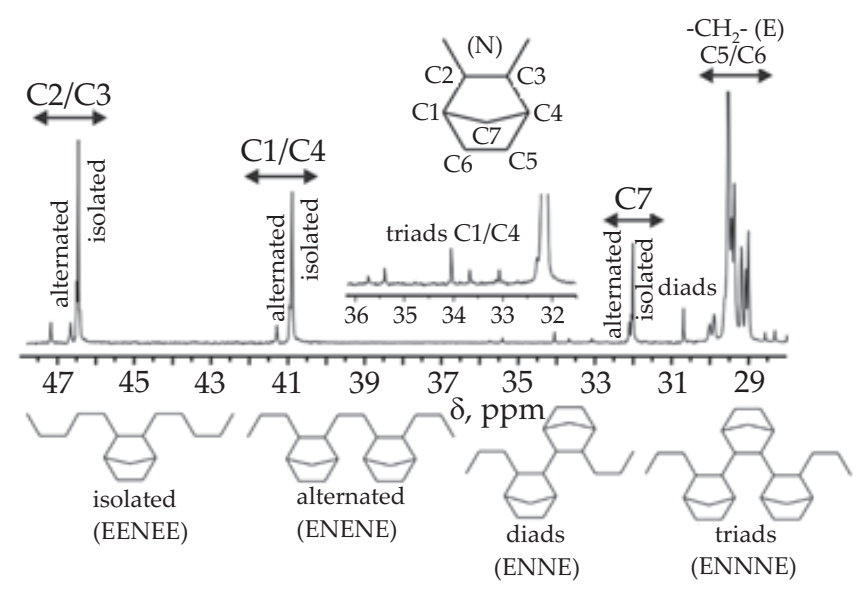

Fig. 1. Schematic ${ }^{13} \mathrm{C}$ NMR spectrum of the ethylene-norbornene copolymer 


\section{SUMMARY}

This review describes the vanadium complexes with various types of ligands used in the copolymerization of ethylene with norbornene. The effect of vanadium complexes and reaction conditions on the catalyst activity and properties of the produced copolymers are also analyzed.

The Et-NB copolymerization with using the presented vanadium catalysts is performed mainly in aromatic solvent, less often in aliphatic hexane, at temperature range $20-50^{\circ} \mathrm{C}$, under ethylene pressure not exceeding $0.8 \mathrm{MPa}$, with initial NB concentration from 0.1 to $2.0 \mathrm{~mol} / \mathrm{dm}^{3}$. The common organoaluminum compounds are used as activators, usually with ethyl trichloroacetate reactivator, methylaluminoxane is seldom used.

The structure of ligand plays a key role in complex stability, however, ligand modifications not always have a significant impact on polyreaction performance as well as copolymer composition and microstructure. The activity of catalysts mainly depends on the type of ligand in the complex, the type and amount of the organoaluminum activator and the initial NB concentration. The highest activity is achieved with the participation of vanadium complex with aminopyridino phenolate ligand $\mathbf{X X X a}$ [70]. The best activator turns out to be $\mathrm{Et}_{2} \mathrm{AlCl}$ with the addition of the ETA reactivator and the increase of its amount in the reaction mixture results in higher amount of the copolymer product. The increase of initial NB concentration up to about $0.6-0.7 \mathrm{~mol} / \mathrm{dm}^{3}$ results in an improvement of the activity of most vanadium catalysts, while a further increase of NB concentration causes the reaction efficiency remain at a comparable level or decrease. The presence of electron withdrawing groups at the vanadium coordination sphere improves the catalyst activity. This relationship is particularly well visible for the complexes with phosphine and amine ligands. For the imido ligand complexes, an additional aryloxy ligand has to be introduced in order to increase the reaction yield. Among the vanadium compounds with the salicylaldiminato ligand and the $\pi$-donor heteroatom, the highest activity is achieved when the electron donor atom is phosphorus. In order to achieve high activities, the ligand in the complex should contain amine or amide nitrogen atom. In most complexes, the presence of aromatic substituents is more favorable than aliphatic, as well as the presence of halogen atoms in the substituents. It seems that the best results are obtained with the use of bi- or tridentate ligands, while the use of a binuclear complex does not significantly affect catalytic activity. The degree of incorporation of norbornene depends primarily on the initial NB concentration and the type of activator. Generally, an increase of the initial NB concentration results in an increase of the NB incorporation in the polymer chain. The highest comonomer incorporation in the polymer chain is obtained using the MAO (methylaluminoxane) activator. The highest NB incorporation is achieved for the vanadium complex with $\beta$-enaminoketonato ligand
(XLIX) [81]. In most cases, the structure of the complexes does not affect the microstructure of the copolymers, in which the isolated and alternating NB units are observed. The exceptions are complexes with oxazoline and oxazine ligands, and the $\mathrm{Cp}_{2} \mathrm{VCl}_{2}$ metallocene catalyst, which copolymers contain the NB diads and triads. The Et-NB copolymers obtained using the vanadium compounds are characterized by high molecular weight reaching the value up to million $\mathrm{g} / \mathrm{mol}$ and narrow, monomodal molecular weight distributions (usually about 2.0), regardless of the catalyst structure. The size of the macromolecules is determined by the initial NB concentration, the structure of ligand and the type of activator. In general, the molecular weight rises with the increase of initial NB concentration. The largest copolymer $M_{w}$ is obtained using the vanadium catalyst with imido and 2-benzimidazolopyridine ligand (XIX) [64]. The obtained copolymers are characterized by the uniform incorporation of NB units into the polymer chain. The use of binuclear catalysts does not significantly change the microstructure and properties of the Et-NB copolymers. Heterogenization of the vanadium complexes on SIL systems allows improving the stability and activity of the catalysts, higher degree of comonomer incorporation in the polymer chain and higher molecular weights of macromolecules.

In summary, the amine complexes are characterized by extremely high activity, exceeding even $106 \mathrm{~kg} / \mathrm{mol}_{\mathrm{V}} \cdot \mathrm{h}$ and the ability to produce polymers with molecular weight above $10^{6} \mathrm{~g} / \mathrm{mol}$. In contrast, the activity of phosphine complexes generally does not exceed $4000 \mathrm{~kg} / \mathrm{mol}_{\mathrm{V}} \cdot \mathrm{h}$ and the copolymers obtained have relatively low $M_{w}$ and wide $M_{w} / M_{n}$. However, they can achieve very high NB incorporation even at low initial comonomer concentration. The complexes with $\beta$-enaminoketonato and salicylaldiminato ligands show good or very good activity and give polymers with high comonomer incorporation even at low NB concentration in feed, with the smallest $M_{w}$ and narrowest $M_{w} / M_{n}$ among the vanadium compounds discussed, especially for those $\beta$-enaminoketonato ligand. Satisfactory activity can be obtained using oxazoline complexes, which give products with very high molecular weight. The vanadium compounds with imido ligands are characterized by high activity and can produce polymers with extremely $M_{w^{\prime}}$ even above $9 \cdot 10^{6} \mathrm{~g} / \mathrm{mol}$. However, they show the weakest ability of NB incorporation, above $30 \mathrm{~mol} \%$ is achieved only at high initial NB concentration.

\section{REFERENCES}

[1] Welz B., Sperling M.: "Atomabsorptionsspektrometrie", John Wiley \& Sons, Weinheim 2012, p. 1857.

[2] Vilter H.: Metal Ions in Biological Systems 1995, 31, 325.

[3] Christman D.L., Keim G.I.: Macromolecules 1968, 1, 358.

https://doi.org/10.1021/ma60004a017

[4] Lorber C.: Coordination Chemistry Reviews 2016, 308, 76. 
https://doi.org/10.1016/j.ccr.2015.02.021

[5] Crans D.C., Smee J.J.: "Comprehensive Coordination Chemistry II", (Eds. McCleverty J.A., Meyer T.J., Wedd A.G.) Elsevier, Amsterdam 2004, p. 175.

[6] Nomura K., Zhang W.: Chemical Science 2010, 1, 161. https://doi.org/10.1039/C0SC00163E

[7] Pellissier H.: Coordination Chemistry Reviews 2015, 284, 93.

https://doi.org/10.1016/j.ccr.2014.09.014

[8] Nomura K., Zhang S.: Chemical Reviews 2011, 111, 2342.

https://doi.org/10.1021/cr100207h

[9] Wu J.Q., Li Y.S.: Coordination Chemistry Reviews 2011, 255, 2303.

https://doi.org/10.1016/j.ccr.2011.01.048

[10] Gambarotta S.: Coordination Chemistry Reviews 2003, 237, 229.

https://doi.org/10.1016/S0010-8545(02)00298-9

[11] Hagen H., Boersma J., van Koten G.: Chemical Society Reviews 2002, 31, 357. https://doi.org/10.1039/b205238e

[12] Natta G., Zambelli A., Lanzi G. et al.: Die Makromolekulare Chemie 1965, 81, 161. https://doi.org/10.1002/macp.1965.020810118

[13] Zambelli A., Pasquon I., Signorini R. et al.: Die Makromolekulare Chemie 1968, 112, 160. https://doi.org/10.1002/macp.1968.021120115

[14] Natta G., Mazzanti G., Valvassori A. et al.: Journal of Polymer Science 1961, 51, 411.

https://doi.org/10.1002/pol.1961.1205115603

[15] Soshnikov I.E., Semikolenova N.V., Bryliakov K.P. et al.: Journal of Organometallic Chemistry 2018, 867, 4. http://dx.doi.org/10.1016/j.jorganchem.2017.08.020

[16] EP 0156464 B1 (1985).

[17] Noordermeer J.W.M.: "Kirk-Othmer Encyclopedia of Chemical Technology" Vol. 10, 5th Ed., J. Wiley \& Sons, New York 2005, p. 704.

[18] Redshaw C.: Dalton Transactions 2010, 39, 5595. https://doi.org/10.1039/B924088H

[19] Clowes L., Walton M., Redshaw C. et al.: Catalysis Science and Technology 2013, 3, 152. https://doi.org/10.1039/c2cy20571h

[20] Ma J., Zhao K.Q., Walton M. et al.: Dalton Transactions 2014, 43, 16698. https://doi.org/10.1039/C4DT01448K

[21] Ma J., Zhao K.Q., Walton M.J. et al: Dalton Transactions 2014, 43, 8300. https://doi.org/10.1039/c4dt00021h

[22] Redshaw C., Walton M., Michiue K. et al:: Dalton Transactions 2015, 44, 12292. https://doi.org/10.1039/ C5DT00376H

[23] Redshaw C., Walton M.J., Elsegood M.R.G. et al.: RSC Advances 2015, 5, 89783. https://doi.org/10.1039/C5RA20177B

[24] Redshaw C., Walton M.J., Lee D.S. et al.: Chemistry: A European Journal 2015, 21, 5199. https://doi.org/10.1002/chem.201406084
[25] Cheng X.P., Fenf L.F., Gu X.P. et al.: Reaction Engineering, Kinetics and Catalysis 2019, 66, 316784. https://doi.org/10.1002/aic.16784

[26] Zanhin G., Bertini F., Vendier L. et al.: Polymer Chemistry 2019, 10, 6200.

https://doi.org/10.1039/C9PY01415B

[27] Henrici-Olivé G., Olivé S.: Angewandte Chemie 1971, 10,776 .

https://doi.org/10.1002/anie.197107761

[28] Feghali K., Harding D.J., Reardon D. et al.: Organometallics 2002, 21, 968. https://doi.org/10.1021/om011040u

[29] Zhao W., Nomura K.: Catalysts 2016, 6, 175. https://doi.org/10.3390/catal6110175

[30] Leone G., Pierro I., Zanchin G. et al.: Journal of Molecular Catalysis A: Chemical 2016, 424, 220. https://doi.org/10.1016/j.molcata.2016.09.002

[31] Tritto I., Boggioni L., Ferro D.R.: Coordination Chemistry Reviews 2006, 250, 212. https://doi.org/10.1016/j.ccr.2005.06.019

[32] Li X., Hou Z.: Coordination Chemistry Reviews 2008, 252, 1842. https://doi.org/10.1016/j.ccr.2007.11.027

[33] https://topas.com/ sites/default/files/files/TOPAS Brochure_E_2014_06(1).pdf (access data 27.02.2020).

[34] Pei L., Tang Y., Gao H.: Polymers 2016, 8, 69. https://doi.org/10.3390/polym8030069

[35] Leone G., Mauri M., Losio S. et al.: Polymer Chemistry 2014, 5, 3412. https://doi.org/10.1039/C3PY01674A

[36] Nomura K., Wang W., Fujiki M. et al.: Chemical Communications 2006, 2659. https://doi.org/10.1039/b605005k

[37] Makio H., Terao H., Iwashita A. et al.: Chemical Reviews 2011, 111, 2363.

https://doi.org/10.1021/cr100294r

[38] Chen M., Zou W., Cai Z. et al.: Polymer Chemistry 2015, $6,2669$. https://doi.org/10.1039/C5PY00010F

[39] Ravasio A., Boggioni L., Tritto I.: Macromolecules 2011, $44,4180$. https://doi.org/10.1021/ma2006427

[40] Li Y., Gao M., Gao H. et al.: European Polymer Journal 2011, 47, 1964. https://doi.org/10.1016/j.eurpolymj.2011.07.012

[41] Zhao M., Chen C.: ACS Catalysis 2017, 7, 7490. https://doi.org/10.1021/acscatal.7b02564

[42] Chen M., Chen C.: ACS Catalysis 2017, 7, 1308. https://doi.org/10.1021/acscatal.6b03394

[43] Na Y., Zhang D., Chen C.: Polymer Chemistry 2017, 8, 2405. https://doi.org/10.1039/C7PY00127D

[44] Song G., Pang W., Li W. et al.: Polymer Chemistry 2017, 8,7400 . https://doi.org/10.1039/C7PY01661A

[45] Li X., Baldamus J., Hou Z.: Angewandte Chemie International Edition 2005, 44, 962. https://doi.org/10.1002/anie.200461971 
[46] Ravasio A., Zampa C., Boggioni L.et al.: Macromolecules 2008, 41, 9565 https://doi.org/10.1021/ma802448n

[47] Burt J., Levason W., Reid G.: Coordination Chemistry Reviews 2009, 260, 65. https://doi.org/10.1016/j.ccr.2013.09.020

[48] Cheng C., Hartwig J.F.: Science 2014, 343, 853. https://doi.org/10.1126/science.1248042

[49] Scheuermann M.L., Johnson E.J., Chirik P.J.: Organic Letters 2015, 17, 2716. https://doi.org/10.1021/acs.orglett.5b01135

[50] Murai M., Takeshima H., Morita H. et al.: The Journal of Organic Chemistry 2015, 80, 5407. https://doi.org/10.1021/acs.joc.5b00920

[51] Ricci G., Sommazzi A., Masi F. et al.: Coordination Chemistry Reviews 2010, 254, 661. https://doi.org/10.1016/j.ccr.2009.09.023

[52] Zanchin G., Vendier L., Pierro I. et al.: Organometallics 2018, 37, 3181. https://doi.org/10.1021/acs.organomet.8b00502

[53] Zanchin G., Pierro I., Parisini E.: Journal of Organometallic Chemistry 2018, 861, 142. https://doi.org/10.1016/j.jorganchem.2018.02.042

[54] Zanchin G., Gavezzoli A., Bertini F. et al.: Molecules 2019, 24, 2088. https://doi.org/10.3390/molecules24112088

[55] Yoshida Y., Mohri J.I., Ishii S.I. et al.: Journal of the American Chemical Society 2004, 126, 12023. https://doi.org/10.1021/ja048357g

[56] Lasarov H., Mönkkönen K., Pakkanen T.: Macromolecular Chemistry and Physics 1998, 199, 1939. ht t p s: // d o i org/10.1002/( S I C I ) 1521 $3935(19980901) 199: 9<1939$ : : A I D MACP1939>3.0.CO;2-F

[57] Zhao W., Yan Q., Tsutsumi K. et al.: Organometallics 2016, 35, 1895. https://doi.org/10.1021/acs.organomet.6b00242

[58] van Doremaele G., van Duin M., Valla M. et al.: Journal of Polymer Science Part A: Polymer Chemistry 2017, 55, 2877. https://doi.org/10.1002/pola.28634

[59] Flisak Z., Sun W. H.: ACS Catalysis 2015, 5, 4713. https://doi.org/10.1021/acscatal.5b00820

[60] Coles M.P., Gibson V.C.: Polymer Bulletin 1994, 33, 529. https://doi.org/10.1007/BF00296160

[61] Coles M.P., Dalby C., Gibson V.C. et al.: Journal of Organometallic Chemistry 1999, 591, 78. https://doi.org/10.1016/S0022-328X(99)00452-0

[62] Nomura K., Bahuleyan B.K., Zhang S. et al.: Inorganic Chemistry 2014, 53, 607. https://doi.org/10.1021/ic402747d

[63] Nagai G., Mitsudome T., Tsutsumi K. et al.: Journal of the Japan Petroleum Institute 2017, 60, 256. https://doi.org/10.1627/jpi.60.256

[64] Nomura K., Oshima M., Mitsudome T. et al.: ACS Omega 2017, 2, 8660.

https://doi.org/10.1021/acsomega.7b01225

[65] Wang W., Nomura K.: Macromolecules 2005, 38, 5905. https://doi.org/10.1021/ma050629s

[66] Wang W., Nomura K.: Advanced Synthesis \& Catalysis 2006, 348, 743.

https://doi.org/10.1002/adsc.200505446

[67] Nomura K., Tsutsumi K., Nagai G. et al.: Journal of the Japan Petroleum Institute 2018, 61, 282.

https://doi.org/10.1627/jpi.61.282

[68] Diteepeng N., Tang X., Hou X.et al.: Dalton Transactions 2015, 44, 12273.

https://doi.org/10.1039/c4dt04026k

[69] Wu J.Q., Mu J.S., Zhang S.W. et al.: Journal of Polymer Science: Part A: Polymer Chemistry 2010, 48, 1122. https://doi.org/10.1002/pola.23868

[70] Wang J.B., Lu L.P., Liu J.Y. et al.: Dalton Transactions 2014, 43, 12926.

https://doi.org/10.1039/c4dt01166j

[71] Wang J.B., Lu L.P., Liu J.Y. et al.: Journal of Polymer Science: Part A: Polymer Chemistry 2015, 398, 289. http://dx.doi.org/10.1016/j.molcata.2014.12.016

[72] Tomov A.K., Gibson V.C., Zaher D. et al.: Chemical Communications 2004, 10, 1956. https://doi.org/10.1039/b407065h

[73] Lorber C., Wolff F., Choukroun R. et al.: European Journal of Inorganic Chemistry 2005, 14, 2850. https://doi.org/10.1002/ejic.200500149

[74] Lorber C.: Pure and Applied Chemistry 2009, 81, 1205. https://doi.org/10.1351/PAC-CON-08-08-05

[75] Long Y.Y., Wang Y.X., Li B.X. et al.: Journal of Polymer Science: Part A: Polymer Chemistry 2017, 55, 2787. https://doi.org/10.1002/pola.28681

[76] Hong M., Yang G.F., Long Y.Y. et al.: Journal of Polymer Science: Part A: Polymer Chemistry 2013, 51, 3144. https://doi.org/10.1002/pola.26699

[77] Yang G., Hong M., Li Y.et al.: Macromolecular Chemistry and Physics 2012, 213, 2311. https://doi.org/10.1002/macp.201200350

[78] Li Y.G., Hong M., Zhang G.B. et al.: Chinese Journal of Polymer Science 2013, 31, 574. https://doi.org/10.1007/s10118-013-1249-0

[79] Tao P., Tang X.Y., Li B.X. et al.: Dalton Transactions 2012, 41, 7390. https://doi.org/10.1039/c2dt30326d

[80] Tang L.M., Wu J.Q., Duan Y.Q.et al.: Journal of Polymer Science: Part A: Polymer Chemistry 2008, 46, 2038. https://doi.org/10.1002/pola.22538

[81] Wang K.T., Wang Y.X., Wang B. et al.: Chinese Journal of Polymer Science 2017, 35, 1110. https://doi.org/10.1007/s10118-017-1956-z

[82] Ochędzan-Siodłak W., Bihun A.: Polymer Bulletin 2017, 74, 2799. https://doi.org/10.1007/s00289-016-1866-1

[83] Lu L.P., Wang K.T., Liu Y., Wu J.J.: Acta Polymerica Sinica 2020,51, 174. https://doi.org/10.11777/j. issn1000-3304.2019.19128

[84] Wang K., Cui L., Li Y., Li Y.: Journal of Polymer Science \& Applications 2017, 1 (1). 
[85] Tshuva E.Y., Goldberg I., Kol M.: Journal of the American Chemical Society 2000, 122, 10706. https://doi.org/10.1021/ja001219g

[86] Tshuva E.Y., Goldberg I., Kol M. et al.: Chemical Communications 2000, 5, 379. https://doi.org/10.1039/b000396o

[87] Hu W.Q., Sun X.L., Wang C. et al.: Organometallics 2004, 23, 1684. https://doi.org/10.1021/om0303808

[88] Wang C., Ma Z., Sun X.L. et al.: Organometallics 2006, $25,3259$. https://doi.org/10.1021/om060062j

[89] Gao M., Wang C., Sun X. et al:: Macromolecular Rapid Communications 2007, 28, 1511. https://doi.org/10.1002/marc.200700305

[90] Yang X.H., Sun X.L., Han F.B.: Organometallics 2008, 27, 4618. https://doi.org/10.1021/om800302f

[91] Gao M.L., Sun X.L., Gu Y.F. et al.: Journal of Polymer Science: Part A: Polymer Chemistry 2008, 46, 2807. https://doi.org/10.1002/pola.22614

[92] Yang X.H., Liu C.R., Wang C. et al.: Angewandte Chemie International Edition 2009, 48, 8099. https://doi.org/10.1002/anie.200903334

[93] Wu J.Q., Pan L., Liu S.R. et al.: Journal of Polymer Science: Part A: Polymer Chemistry 2009, 47, 3573. https://doi.org/10.1002/pola.23441

[94] Wu J.Q, Pan L., Li Y.G. et al.: Organometallics 2009, 28, 1817. https://doi.org/10.1021/om801028g

[95] Hafeez M., Lippert S., Bauer T. et al.: Journal of the Iranian Chemical Society 2015, 12, 957. https://doi.org/10.1007/s13738-014-0558-8

[96] Imanishi Y., Nomura K.: Journal of Polymer Science: Part A: Polymer Chemistry 2000, 38, 4613.

h t t p : / / d x.d o i.org / $10.1002 / 1099$ 0518(200012)38:1+<4613::AID-POLA10>3.0.CO;2-N

[97] Ochędzan-Siodłak W., Bihun-Kisiel A., Siodłak D. et al.: European Polymer Journal 2018, 106, 148. https://doi.org/10.1016/j.eurpolymj.2018.07.019

[98] Ochędzan-Siodłak W., Siodłak D., Piontek A. et al.: Catalysts 2019, 9, 1041. https://doi.org/10.3390/cata19121041

Received 27 IV 2020.

\section{W kolejnym zeszycie ukażą się m.in. następujące artykuły:}

K. Wiśniewska, Z. Rybak, M. Wątrobiński, M.H. Struszczyk, J. Filipiak, B. Żywicka, M. Szymonowicz - Bioresorbowalne materiały polimerowe -- obecny stan wiedzy (j. ang.)

G. Korbecka-Glinka, M. Wiśniewska-Wrona, E. Kopania-Zastosowanie polimerów naturalnych do uszlachetniania materiału siewnego

R. Karaś - Technologia konstrukcji okien z tworzyw polimerowych i ich transport z Polski od 1990 roku (j. ang.)

M.J. Suriani, S.M. Sapuan, C.M. Ruzaidi, J. Naveen, H. Syukriyah, M. Ziefarina - Korelacja defektów produkcyjnych i odporności na uderzenie poliestrowego kompozytu hybrydowego włókno szklane/Kevlar wzmocnionego włóknem kenaf (j. ang.)

N.M.Z. Nik Baihaqi, A. Khalina, N. Mohd Nurazzi, H.A. Aisyah, S.M. Sapuan, R.A. Ilyas - Wpływ zawartości i hybrydyzacji włókien na wytrzymałość na zginanie i skręcanie hybrydowych kompozytów epoksydowych wzmocnionych włóknami węglowymi i włóknami palmy cukrowej (j. ang.)

M. Bieliński, A. Kościuszko, K. Smolińska - Wybrane wskaźniki użytkowe oceny podatności polipropylenu na barwienie pigmentami o różnej odporności na UV (j. ang.)

M. Oleksy, R. Oliwa, K. Bulanda, G. Budzik, Ł. Przeszłowski, M. Magniszewski, A Paszkiewicz-Badania wytrzymałości na skręcanie połączeń wielowypustowych wykonanych z materiałów polimerowych (j.ang.) 